\title{
MELURUSKAN PENAFSIRAN TENTANG PANCASILA
}

\author{
Wira Atma Hajri ${ }^{(1)}$, Zulherman Idris ${ }^{(2)}$, Masriko Riantono ${ }^{(3)}$ \\ Dosen dan Mahasiswa Fakultas Hukum \\ Universitas Islam Riau Jalan Kaharuddin Nasution 113 Pekanbaru, 28284, Riau, Indonesia \\ Email:w.a.hajri@law.uir.ac.id ${ }^{(1)}$,zulhermanidris@law.uir.ac.id ${ }^{(2)}$,rikokurniawan1997@gmail.com ${ }^{(3)}$
}

\begin{abstract}
ABSTRAK
Pancasila memiliki kedudukan yang begitu strategis di dalam kehidupan berbangsa dan bernegara. Pancasila tidak hanya sebagai sumber dari segala sumber hukum, teapi juga sebagai dasar negara, ideologi negara, dan dasar filosofis negara. Kendatipun demikian, ironisnya penafsiran tentang Pancasila itu sendiri malahan beragam. Sederhananya tergantung pemegang kekuasaan. Tujuan penelitian ini adalah untuk mengetahui penafsiran yang benar tentang Pancasila di Indonesia terutama sila Ketuhanan Yang Maha Esa yang menyinari sila-sila yang lain. Penelitian ini adalah penelitian kepustakaan. Analisis data dilakukan secara kualitatif dengan menggunakan pendekatan perundang-undangan, pendekatan kasus, pendekatan konseptual, dan pendekatan historis, pendekatan politik, serta pendekatan perbandingan. Hasil penelitian ini adalah bahwa adanya penyimpangan terhadap Pancasila ketika Pancasila tidak ditafsirkan secara benar dan tidak mau jujur dengan sejarah perumusan Pancasila itu sendiri. Karenanya tak mengherankan bilamana di dalam praktiknya, terdapat peraturan perundang-undangan, paham-paham, perbuatan atau tindakan yang bertentangan dengan Pancasila.
\end{abstract}

\section{Kata Kunci: Pancasila, Penafsiran, Kekuasaan, Agama}

\section{ABSTRACT}

Pancasila has a very strategic position in the life of the nation and state. Pancasila is not only as a source of all sources of law, but also as the basis of the state, state ideology, and philosophical basis of the state. Nevertheless, ironically the interpretation of Pancasila itself is even diverse. It simply depends on the holder of power. The purpose of this study is to find out the correct interpretation of Pancasila in Indonesia, especially the principle of the Almighty God who illuminates the other precepts. This research is a library research. Analysis was carried out qualitatively using a statutory approach, case approach, conceptual approach, and historical approach, political approach, and comparison approach. The results of this study are that there is a deviation from Pancasila when Pancasila is not interpreted correctly and does not want to be honest with the history of the formulation of Pancasila itself. Therefore it is not surprising when in practice, there are laws, understandings, actions or actions that are contrary to Pancasila.

Keywords: Pancasila, Interpretation, Power, Religion 


\section{PENDAHULUAN}

\section{A. Latar Belakang}

Pasal 2 Undang-Undang Nomor 12 Tahun 2011 Tentang Pembentukan Peraturan PerundangUndangan menyebutkan bahwa, "Pancasila merupakan sumber segala sumber hukum negara". Bahkan di dalam penjelasan undang-undang ini, Pancasila juga disebut sebagai dasar negara, ideologi negara, dan dasar filosofis negara.

Mencermati Pasal 2 di atas beserta penjelasannya itu, dapat disimpulkan bahwa begitu strategisnya posisi Pancasila di Indonesia. Bahkan dalam pengamatan Santoso (2007:101) bahwa, "di tengah masyarakat masih sering terdengar bahwa kita harus membangun negara bedasarkan Pancasila, karena hanya dengan itu persatuan Indonesia terjamin". Kendatipun demikian, Pancasila di dalam praktiknya menuai persoalan yang sangat mendasar. Di mana beragamnya penafsiran tentang Pancasila itu sendiri. Tidak hanya di kalangan warga negara, bahkan itupun terjadi di setiap Presiden yang pernah dan sedang menjabat di republik ini. Singkatnya adalah setiap Presiden memiliki tafsir yang berbeda-beda tentang Pancasila.

Di masa Orde Lama misalkan, Pancasila di bawah pengasuhan Soekarno, paham komunis hidup dan berkembang. Artinya, paham komunis tidak dianggap bertentangan dengan Pancasila. Sebab Soekarno mengasuh Pancasila dalam tafsiran Nasionalis, Agama, dan Komunis. Hal ini berbeda dengan Orde Baru yang dikenal dengan slogannya, yaitu menjalankan Pancasila secara murni dan konsekuen. Di sini, Paham komunis dianggap bertentangan dengan Pancasila. Tak hanya itu, di zaman ini pun partai politik maupun organisasi kemasyarakatan tidak boleh berasaskan Islam. Inilah yang dikenal dengan asas tunggal Pancasila.

Di masa reformasi, Pancasila ditafsirkan lain lagi. Di mana partai politik maupun organisasi kemasyarakatan boleh berasaskan Islam. Di sisi lain juga paham sekuler dan liberal pun semakin tumbuh berkembang. Misalkan agama dan politik harus dipisahkan, penyimpangan seksual semakin subur, demokrasi yang keblabasan, penolakan terhadap Perda Syariah, dan lain sebagainya. Padahal sila pertama Pancasila adalah Ketuhanan Yang Maha Esa.

Bahkan, tafsir beragam terhadap Pancasila pun juga terlihat ketika Pancasila dalam pengasuhan Joko Widodo. Setiap aksi maaupun paham yang bertentangan dengan aksi maupun paham pemerintah acap kali dituduh sebagai aksi maupun paham yang anti terhadap Pancasila. Misalkan dalam hal pembubaran Hizbut Tahrir Indonesia yang dianggap bertentangan dengan Pancasila. Padahal, sepuluh tahun Susilo Bambang Yudhoyono menduduki posisi Presiden Indonesia,
Hizbut Tahrir Indonesia tidak dianggap bertentangan dengan Pancasila.

Adapun masalah pokok penelitian ini adalah, bagaimana menafsirkan Pancasila yang benar terutama terkait dengan sila Ketuhanan Yang Maha Esa yang merupakan sila yang mewarnai sila-sila yang lain? Karena itu, tujuan penelitian ini adalah untuk mengetahui penafsiran yang benar tentang Pancasila terutama sila Ketuhanan Yang Maha Esa.

\section{STUDI KEPUSTAKAAN}

Penalaran hukum adalah penerapan prinsipprinsip berpikir lurus (logika) dalam memahami prinsip, aturan, data, fakta, dan proposisi hukum (Weruin, 2017: 392). Hal ini penting dilakukan, sebab prinsip, aturan, data, fakta, dan proposisi hukum, tidak lah berada di ruang hampa. Sehingga dengan demikian, kegiatan penalaran ini berbeda negara satu dengan negara lainnya (Faiz, 2016: 410). Salah satu bentuk penalaran hukum ini adalah penggunaan metode penafsiran.

Kegiatan penafsiran itu bukanlah kegiatan yang sederhana. Karena itu, di dalam kegiatan penafsiran ada metode atau ilmu yang digunakan. Kegiatan penafsiran itu adalah bagaimana memperlakukan teks dan bersikap pada konteks. Sehingga, jika salah tafsir, maka akan menimbulkan kesalahpahaman di dalam melihat obyek yang ditafsirkan itu. Lebih tepatnya adalah penyimpangan terhadap makna teks atau dalam bahasa lain adalah tafsir sesat. Ini lah yang terjadi dengan Pancasila.

Di dalam ilmu hukum dikenal beberapa metode penafsiran, di antaranya:

1. Penafsiran gramatikal adalah penafsiran yang didasarkan kepada bahasa yang dipahami secara luas dan lazim di dalam kehidupan sehari-hari. (Mertokusumo dan A. Pitlo, 1993: 14-15). Kendatipun demikian, tetap saja jenis penafsiran yang satu ini dapat dipertanggungjawabkan secara ilmiah. Misalkan, kata "demokratis" yang terdapat di dalam Pasal 18 Ayat 4 UUD 1945. Dari situ dapat dipahami bahwa setiap kepala daerah mesti dipilih. Baik pemilihan itu dilakukan oleh rakyat secara langsung, melalui pemilu maupun melalui pemilihan secara perwakilan oleh DPRD. Kedua-duanya sama-sama demokratis.

2. Penafsiran logis adalah penafsiran yang dilakukan dengan cara mengaitkan ataupun menghubungan peraturan yang satu dengan peraturan yang lain (Mertokusumo, 1993: 76). Dengan demikianlah dapat ditarik makna pasal atau peraturan tersebut. Karena itu pula penafsiran ini juga dikenal dengan sebutan penafsiran sistematis. Misalkan mengenai apa yang dimaksud dengan pemilu di dalam Pasal 24 C Ayat (1) UUD 1945. Memberikan 
tafsiran tentang kata pemilu di dalam pasal ini menjadi penting ketika dikaitkan dengan salah satu kewenangan dari MK, yaitu mengadili sengketa hasil pemilu. Setelah ditelusuri di dalam UUD 1945, dapat ditemukan tentang sengketa hasil pemilihan mana yang dapaty diadili oleh MK yaitu pemilihan Presiden, DPR, DPD, dan DPRD. Hal ini didasarkan kepada Pasal 22 E Ayat (2) UUD 1945.

3. Penafsiran sosiologis adalah penafsiran yang dilakukan dengan cara memahami peraturan yang ada sesuai dengan apa yang dimaksudkan ketika dibentuk oleh pembuat peraturan. Atau dalam bahasa lain, yaitu sesuai dengan peruntukannnya (Mertokusumo, 1993: 78). Hal ini tidak dapat dipungkiri bahwa setiap kasus pada dasarnya memiliki latar belakang yang berbeda-beda, kendatipun terkadang secara formal ada kemiripan. Sebagai contoh, suatu ketika khalifah Umar bin Khattab tidak menghukum pencuri yang disebabkan karena kelaparan atau penelantaran oleh majikannya. Sebab, ayat tentang pencuri dihukum dengan hukuman potong tangan yang ada di dalam Al-Qur'an, tidaklah dimaksudkan bagi orang yang mencuri karena kelaparan.

4. Penafsiran historis adalah pemahaman terhadap obyek yang dikaji dengan dengan cara menelusuri sejarah pembentukannya. (Mertokusumo, 1993: 79). Salah satu penerapan penafsiran ini adalah ketika MK memutuskan bahwa hakim konstitusi tidaklah di bawah pengawasan KY. Hanya hakim agung dan hakim di bawahnya sajalah yang dapat diawasi oleh KY. Hal ini di dasarkan kepada sejarah perumusan Pasal 24 B UUD 1945 tentang KY.

5. Penafsiran komparatif adalah penafsiran yang dilakukan dengan jalan memperbandingkan antara beberapa aturan hukum. Tujuan hakim memperbandingkan adalah dimaksudkan untuk mencari kejelasan mengenai makna dari suatu ketentuan undang-undang (Mertokusumo dan A. Pitlo, 1993: 79).

6. Penafsiran antisipatif adalah pemahaman terhadap norma melalui pemahaman terhadap norma peraturan perundang-undangan yang belum mempunyai kekuatan berlaku. Penafsiran ini juga dikenal dengan sebutan penafsiran futuristis (Sudikno Mertokusumo dan A. Pitlo, 1993: 80)

7. Penafsiran otentik adalah pemahaman terhadap peraturan berdasarkan batasan yang telah ditentukan oleh peraturan itu sendiri. Hal ini biasanya dapat kita jumpai pada bagian bagian ketentuan penjelasan (memorie van toelichting). Tau bisa juga dilihat pada bagian ketentuan umum peraturan tersebut, bahkan juga dicantumkan pada pasal lainnya (Shidarta, 2013: 169). Misalkan penafsiran terhadap istilah "peraturan perundangundangan". Makna dari "peraturan perundang-undangan" ini dapat dilihat di dalam ketentuan umum UU Nomor 12 Tahun 2011.

8. Penafsiran evolusi dinamik adalah pemahaman terhadap norma dengan cara melihat kondisi di lapangan pada masa mendatang (Manan, 2004: 77). Sebagai contoh adalah adanya putusan inkonstitusional bersyarat dan konstitusional bersyarat dari MK seperti penggunaan KTP atau pasport bagi WNI untuk menggunakan hak untuk memilih di dalam pemilu dikarenakan tidak terdaftar pada DPT.

Kendatipun beberapa metode penafsiran di atas biasanya digunakan untuk menafsirkan undang-undang, menurut hemat Peneliti, metode ini dapat juga digunakan untuk menafsirkan silasila yang ada di dalam Pancasila. Sebab, sila-sila Pancasila tersebut juga dirumuskan dalam bahasa hukum. Sehingga memahami Pancasila tidak berdasarkan nafsu belaka. Karena "Panca" itu lima, "sila" itu dasar, maka "lima dasar" itu harus ditafsirkan. Lagi pula di sisi yang lain, Pancasila juga memiliki latar belakang perumusan baik perihal agama, sejarah, politik, maupun latar belakang sosial.

\section{METODE PENELITIAN}

Penelitian ini adalah penelitian hukum normatif atau penelitian kepustakaan. Konsekuensi dari pilihan jenis penelitian ini adalah bahwa permasalahan yang akan dikaji dilakukan dengan cara meneliti bahan-bahan pustaka atau data sekunder saja (Susanti dan A'an Efendi, 2013: 19).

Data yang digunakan di dalam penelitian ini adalah data sekunder. Data ini terdiri dari:

1. Bahan hukum primer yang terdiri atas peraturan perundang-undangan, risalah resmi, putusan pengadilan, dan dokumen resmi negara (Marzuki, 2005: 141-149).

2. Bahan hukum sekunder yang terdiri atas buku atau jurnal hukum yang berisi mengenai prinsip-prinsip dasar hukum (asas hukum), pendapat atau pandangan ahli hukum (doktrin), hasil penelitian hukum, kamus hukum, dan ensiklopedia ilmu hukum. Di samping itu, dapat diartikan juga sebagai bahan hukum sekunder adalah wawancara yang dilakukan dengan narasumber seorang ahli hukum untuk memberikan pendapat hukum tentang suatu fenomena yang menjadi obyek penelitian. Tentu saja, ahli hukum yang diwawancara tersebut adalah orang yang independen sehingga pandangan yang disampaikannya pun lebih obyektif (Marzuki, 
2005: 141-149). Bahan hukum sekunder yang digunakan adalah buku dan jurnal hukum yang terkait dengan permasalah yang dikaji.

3. Bahan non-hukum yang terdiri atas buku teks bukan hukum yang terkait dengan penelitian seperti buku politik, buku ekonomi, kamus bahasa, data sensus, laporan tahunan perusahaan, dan ensiklopedia umum. Kendatipun bahan ini adalah bahan nonhukum, namun bahan ini menjadi penting dalam sebuah penelitian hukum dikarenakan dapat membantu peneliti untuk menganalisis aspek hukumnya (Marzuki, 2005: 141-149). Berdasarkan uraian tentang bahan non-hukum ini, peneliti hanya menggunakan buku politik. Pengumpulan data di dalam penelitian ini dilakukan melalui penelusuran terhadap data sekunder yang terkait baik untuk bahan hukum primer, bahan hukum sekunder, maupun bahan non-hukum. Setelah data ini terkumpul, data akan dianalisis secara kualitatif dengan menggunakan pendekatan perundang-undangan, pendekatan kasus, pendekatan konseptual, dan pendekatan historis, serta pendekatan politik. Setelah itu, hasil analisis ini akan dipaparkan secara deskriptif. Terakhir, dari itu semua akan dilakukan penarikan kesimpulan melalui medode deduksi.

\section{HASIL DAN PEMBAHASAN}

Di dalam menafsirkan Pancasila, tidak tepat bilamana tidak memperhatikan sejarah perumusannya. Inilah yang disebut dengan metode penafsiran historis yang merupakan salah satu metode penafsiran yang diakui keberadaannya di dalam studi ilmu hukum.

Di lihat dari sisi sejarah pembentukan, Pancasila terutama sila pertama Ketuhanan Yang Maha Esa tidak bisa dilepaskan dari sejarah pencoretan "tujuh kata" yang berasal dari Piagam Jakarta yang telah disepakati oleh para perumusnya ketika itu. Di dalam Piagam Jakarta itu, sila pertama ini berbunyi, "Ketuhanan dengan Kewajiban Menjalankan Syariat Islam bagi Pemeluk-pemeluknya". Hatta menceritakan di dalam bukunya, Sekitar Proklamsi Kemerdekaan 17 Agustus 1945, sebagaimana dikutip oleh Adian Husaini (2009: 24), bahwa:

“...wakil-wakil Protestas dan Katolik dalam kawasan Kaigun berkeberatan sangat atas anak kalimat dalam pembukaan UUD yang berbunyi "Ketuhanan dengan Kewajiban Menjalankan Syariat Islam bagi Pemeluk-pemeluknya”. Walaupun mereka mengakui bahwa anak kalimat tersebut tidak mengikat mereka, dan hanya mengikat rakyat yang beragama Islam, namun mereka memandangnya sebagai diskriminasi terhadap mereka golongan minoritas... kalau Pembukaaan diteruskan juga apada adanya, maka golongan Protestan dan Katolik lebih suka berdiri di luar Republik".

Mencermati pernyataan Hatta ini, inilah jawaban mengapa ketika proklamasi dibacakan ketika itu, tidak ada satupun tokoh Kristen yang hadir padahal ini adalah momentum yang paling bersejarah dalam pembentukan sebuah negara. Terlepas itu semua, pada akhirnya Hatta menyampaikan keluhan pihak Kristen ini kepada beberapa tokoh bangsa ketika itu. Ki Bagus Hadikusumo adalah tokoh yang paling konsisten untuk menolak perubahan itu dengan dalih bahwa Soekarno dan Hatta adalah dua tokoh yang selalu mengagung-agungkan kesepakatan bangsa, namun pada saat itu malahan mereka yang meminta untuk dihapus.

Menariknya adalah bahwa Soekarno ketika itu memilih untuk tidak menjawab protes dari $\mathrm{Ki}$ Bagus itu. Namun di sisi yang lain, Hatta tetap melanjutkan pembicaraan ini dengan menaruh harapan kepada Kasman dan Teuku Muhammad Hasan yang merupakan anggota tambahan PPKI utusan Bung Karno.

Lobi yang dilakukan oleh Kasman dan Teuku Muhammad Hasan pada awalnya sama sekali tidak mampu membuat $\mathrm{Ki}$ Bagus untuk mengubah pandangannya itu. Namun, Hatta terus saja mendorong Kasman untuk melobi Ki Bagus Hadikusumo, pimpinannya di Muhammadiyah. Hatta berpandangan negara dalam keadaan darurat. Di sisi lain juga, Sekarno pun menjanjikan bahwa nanti akan disusun kembali dasar negara jika kondisi negara sudah aman.

Pada akhirnya pun Ki Bagus Hadikusukomo tak mampu menolak usulan Kasman. Kasman meyakinkan Ki Bagus bahwa Tuhan Yang Maha Esa itu adalah Allah, tidak lain kecuali Allah. Kasman menjelaskan, Ketuhanan Yang Maha Esa menentukan Ketuhanan di dalam Pancasila. Sekali lagi bukan Ketuhanan sembarang Ketuhanan, tetapi yang dikenal Pancasila adalah Ketuhanan Yang Maha Esa (Artawijaya, 2012:188).

Untuk menguatkan perubahan sikapnya itu, Ki Bagus pun meminta penjelasan Hatta tentang siapa yang dimaksud Tuhan Yang Maha Esa itu. Ki Bagus menegaskan kepada Hatta bahwa makna Tuhan Yang Maha Esa itu adalah tauhid. Tuhan Yang Maha Esa itu adalah Allah. Hatta pun meyakinkan Ki bagus bahwa dia sepakat dengan pandangan itu. Bahwa Ketuhanan Yang Maha Easa itu adalah Allah, tidak lain kecuali Allah. Menurut Hatta, ia mengusulkan sila Ketuhanan Yang Maha Esa dijadikan sila pertama supaya Allah dengan Nur-Nya menyinarkan Nur-Nya itu kepada sila-sila yang lainnya (Lesus, 2017: 88). Secara gramatikal pun, Tuhan Yang Maha Esa itu adalah Allah.

Untuk menafsirkan sila Ketuhanan Yang Maha Esa tersebut, juga tidak dapat dilepaskan dari penggunaan metode penafsiran sistematis. Kalimat 
Ketuhanan Yang Maha Esa ini tidak hanya terdapat di dalam paragraf ke-4 pembukaan UUD 1945, tetapi juga terdapat di dalam Pasal 29 Ayat (1) UUD 1945. Mencermati siapa yang dimaksud dengan Tuhan Yang Maha Esa itu, jawabanya terdapat di dalam paragraf ke-3 pembukaan UUD 1945, yaitu Allah.

Tidak hanya persoalan penafsiran, penyimpangan dalam menafsirkan Pancasila juga diakibatkan oleh adanya anggapan bahwa Soekarno adalah perumus Pancasila. Berikut lima rumusan Pancasila Resmi dalam sejarah Indonesia:

1. Rumusan I Piagam Jakarta 22 Juni 1945, yang terdiri dari:

a. Ketuhanan dengan kewajiban menjalankan Syariat Islam bagi pemeluk-pemeluknya;

b. Kemanusian yang adil dan beradab;

c. Persatuan Indonseia

d. Kerakyatan yang dipimpin oleh hikmat kebijaksanaan dalam permusyaratan perwakilan;

e. Keadilan sosial bagi seluruh rakyat Indonesia.

2. Rumusan II Pembukaan UUD 1945 (18 Agustus 1945), yang terdiri dari:

a. Ketuhanan Yang Maha Esa;

b. Kemanusian yang adil dan beradab;

c. Persatuan Indonesia;

d. Kerakyatan yang dipimpin oleh hikmat kebijaksanaan dalam permusyaratan perwakilan;

e. Keadilan sosial bagi seluruh rakyat Indonesia.

3. Rumusan III Mukaddimah Konstitusi Republik Indonesia Serikat (27 Desember 1949), yang terdiri dari:

a. Ketuhanan Yang Maha Esa;

b. Peri Kemanusian;

c. Kebangsaan;

d. Kerakyatan;

e. Keadilan sosial.

4. Rumusan IV Mukaddimah UUDS (15 Agustus 1950), yang terdiri dari:

a. Ketuhanan Yang Maha Esa;

b. Peri Kemanusian;

c. Kebangsaan;

d. Kerakyatan;

e. Keadilan sosial.

5. Rumusan V, yaitu Rumusan II yang dijiwai oleh Rumusan I hasil Dekrit Presiden 5 Juli 1959, yang terdiri dari:

a. Ketuhanan Yang Maha Esa;

b. Kemanusian yang adil dan beradab;

c. Persatuan Indonesia;

d. Kerakyatan yang dipimpin oleh hikmat kebijaksanaan dalam permusyaratan perwakilan;

e. Keadilan sosial bagi seluruh rakyat Indonesia.
Rumusan V inilah yang berlaku hari ini. Bandingkan dengan rumusan pribadi Soekarno, 1 Juni 1945, yaitu:

1. Kebangsaan;

2. Internasionalisme atau Peri Kemanusiaan;

3. Mufakat atau Demokrasi;

4. Kesejahteraan Sosial;

5. Ketuhanan.

Bahkan, sebelum 1 Juni ini Muhammad Yamin dan Soepomo telah menyampaikan usulan pribadi mereka tentang dasar negara. Muhammad Yamin pada tanggal 29 Mei 1945 menyampaikan "Lima Dasar", yaitu:

1. Peri Kebangsaan;

2. Peri Kemanusiaan;

3. Peri Ketuhanan;

4. Peri Kerakyatan;

5. Kesejahteraan Rakyat.

Soepomo pada tanggal 31 Mei 1945 menyampaikan "Panca Dharma" yang terdiri dari:

1. Persatuan;

2. Kekeluargaan;

3. Keseimbangan Lahir dan Batin;

4. Musyawarah;

5. Keadilan Rakyat.

Karena itu, hal yang sangat lucu bilamana Joko Widodo menetapkan 1 Juni sebagai hari lahir Pancasila. Sebab Pancasila hari ini berbeda dengan yang diucapkan oleh Soekarno pada tanggal 1 Juni 1945 itu. Pancasila hari ini berasal Dekrit Presiden 5 Juli 1959 dimana secara teks sama dengan Pancasila yang ditetapkan tanggal 18 Agustus 1945, namun Pancasila hari ini dijiwai oleh Piagam Jakarta. Dengan demikian, Pancasila haruslah ditafsirkan bahwa semua peraturan perundangundangan yang sudah ada atau yang akan dibentuk, putusan-putusan hakim, paham-paham yang hidup di dalam negara, dan semua tindakan atau perbuatan pemerintah dan warga negara tidak boleh bertentangan dengan ajaran agama, terlebih lagi ajaran Islam.

Kendatipun demikian, faktanya terdapat penyimpangan di dalam menafsirkan Pancasila itu. Perihal peraturan perundang-undangan misalkan. Di mana terdapat sejumlah peraturan perundangundangan yang betentangan dengan ajaran agama. Sebagai contoh adalah legalisasi terhadap minuman beralkohol atau khamar yang jelas-jelas dilarang oleh agama, terutama Islam melarang keras akan hal itu.

Di Indonesia minuman beralkohol dibenarkan berdasarkan Peraturan Presiden Nomor 74 Tahun 2013 Tentang Pengendalian dan Pengawasan Minuman Beralkohol. Di antara pasal yang menarik untuk diperhatikan adalah Pasal 4 dan Pasal 7. Pasal 4 itu menyebutkan bahwa:

1. Minuman Beralkohol yang berasal dari produksi dalam negeri hanya dapat diproduksi oleh pelaku usaha yang telah memiliki izin 
usaha industri dari menteri yang menyelenggarakan urusan pemerintahan di bidang perindustrian;

2. Minuman Beralkohol yang berasal dari impor hanya dapat diimpor oleh pelaku usaha yang telah memiliki perizinan impor dari menteri yang menyelenggarakan urusan pemerintahan di bidang perdagangan;

3. Minuman Beralkohol hanya dapat diedarkan setelah memiliki izin edar dari kepala lembaga yang menyelenggarakan pengawasan di bidang obat dan makanan;

4. Minuman Beralkohol hanya dapat diperdagangkan oleh pelaku usaha yang telah memiliki izin memperdagangkan Minuman Beralkohol sesuai dengan penggolongannya sebagaimana diatur dalam Pasal 3 ayat (1) dari menteri yang menyelenggarakan urusan pemerintahan di bidang perdagangan.

Pasal 7 berbunyi:

1. Minuman Beralkohol golongan $\mathrm{A}$, golongan $\mathrm{B}$, dan golongan $\mathrm{C}$ hanya dapat dijual di:

a. hotel, bar, dan restoran yang memenuhi persyaratan sesuai peraturan perundangundangan di bidang kepariwisataan;

b. toko bebas bea; dan

c. tempat tertentu selain huruf a dan b yang ditetapkan oleh Bupati/Walikota dan Gubernur untuk Daerah Khusus Ibukota Jakarta;

2. Penjualan dan/atau peredaran Minuman Beralkohol di tempat tertentu yang ditetapkan oleh Bupati/Walikota dan Gubernur untuk Daerah Khusus Ibukota Jakarta sebagaimana dimaksud pada ayat (1) huruf c tidak berdekatan dengan tempat peribadatan, lembaga pendidikan dan rumah sakit;

3. Selain tempat sebagaimana dimaksud pada ayat (1), Minuman Beralkohol golongan A juga dapat dijual di toko pengecer dalam bentuk kemasan.

Mengacu pada ajaran agama, terutama ajaran Islam, Al-Qur'an Surat Al-Maidah Ayat (90-91) menyebutkan bahwa:

"Hai orang-orang yang beriman, Sesungguhnya (meminum) khamar, berjudi, (berkorban untuk) berhala, mengundi nasib dengan panah, adalah Termasuk perbuatan syaitan. Maka jauhilah perbuatan-perbuatan itu agar kamu mendapat keberuntungan. Sesungguhnya syaitan itu bermaksud hendak menimbulkan permusuhan dan kebencian di antara kamu lantaran (meminum) khamar dan berjudi itu, dan menghalangi kamu dari mengingat Allah dan sembahyang; Maka berhentilah kamu (dari mengerjakan pekerjaan itu)".
Tak hanya itu, di dalam hadis yang diriwayatkan oleh Tirmidzi dan Ibn Majah bahwa: "Rasulullah melaknat tentang khamar, sepuluh golongan: yang memerasnya, yang minta diperaskan, yang meminumnya, yang membawanya, yang minta diantarinya, yang menuangkannya, yang menjualnya, yang makan hasil penjualannya, yang membelinya, dan yang minta dibelikannya"?.

Penyimpangan terhadap Pancasila juga terjadi melalui isme atau paham. Di antaranya adalah sekulerisme, pluralisme, dan liberalisme. Terkait dengan beberapa paham ini, bahkan MUI telah mengeluarkan fatwa, yaitu Fatwa MUI Nomor 7/MUNASVII/MUI/11/2005 Tentang Pluralisme, Liberalisme, dan Sekulerisme Agama. Di dalam fawa tersebut, MUI menyebutkan bahwa:

"Pertama: Ketentuan Umum. Dalam fatwa ini, yang dimaksud dengan:

1. Pluralisme agama adalah suatu paham yang mengajarkan bahwa semua agama adalah sama dan karenanya kebenaran setiap agama adalah relatif; oleh sebab itu, setiap pemeluk agama tidak boleh mengklaim bahwa hanya agamanya saja yang benar sedangkan agama yang lain salah. Pluralisme agama juga mengajarkan bahwa semua pemeluk agama akan masuk dan hidup berdampingan di surga.

2. Pluralitas agama adalah sebuah kenyataan bahwa di negara atau daerah tertentu terdapat berbagai pemeluk agama yang hidup secara berdampingan.

3. Liberalisme agama adalah memahami nashnash agama (al-Qur'an \& Sunnah) dengan menggunakan akal pikiran yang bebas; dan hanya menerima doktrin-doktrin agama yang sesuai dengan akal pikiran semata.

4. Sekularisme agama adalah memisahkan urusan dunia dari agama; agama hanya digunakan untuk mengatur hubungan pribadi dengan Tuhan, sedangkan hubungan sesama manusia diatur hanya dengan berdasarkan kesepakatan sosial.

Kedua: Ketentuan Hukum

1. Pluralisme, Sekularisme dan Liberalisme agama sebagaimana dimaksud pada bagian pertama adalah paham yang bertentangan dengan ajaran agama Islam.

2. Umat Islam haram mengikuti paham Pluralisme, Sekularisme dan Liberalisme Agama.

3. Dalam masalah aqidah dan ibadah, umat Islam wajib bersikap eksklusif, dalam arti haram mencampur-adukkan aqidah dan ibadah umat Islam dengan aqidah dan ibadah pemeluk agama lain. 
4. Bagi masyarakat Muslim yang tinggal bersama pemeluk agama lain (pluralitas agama), dalam masalah sosial yang tidak berkaitan dengan aqidah dan ibadah, umat Islam bersikap inklusif, dalam arti tetap melakukan pergaulan sosial dengan pemeluk agama lain sepanjang tidak saling merugikan".

Adanya salam lintas agama yang diucapkan oleh para tokoh di republik ini di berbagai kesempatan adalah wujud nyata dari pluralisme itu sendiri. Ia seorang Muslim, namun dalam salam pembukanya tidak hanya mengucapkan assalamu'alaikum, namun juga ucapan salam di dalam agama lain, yaitu salom, salam sejahtera, namo budhaya, om swastyastu, dan salam kebajikan. Padahal, salam-salam tersebut berkaitan dengan akidah atau keimanan masing-masng agama. Islam melarang hal ini, bukan berarti Islam tidak toleransi. Sebab, di dalam Islam, toleransi itu dipahami dengan menerima perbedaan, namun tetap memegang prinsip. Di dalam bahasa agama, sering kali diucapkan, "untukmu agama mu, dan untuk ku agama ku” (QS. Ali Imran [109]: 6).

Begitu juga dengan sekulerisme. Tidak ada tempat paham ini di Indonesia. Ada beberapa alasan untuk itu. Pertama, sila Pertama Pancasila yang berbunyi bahwa, "Ketuhanan Yang Mahasa Esa”. Kedua, Pasal 28 J Ayat (2) UUD 1945 bahwa, "Dalam menjalankan hak dan kebebasannya, setiap orang wajib tunduk kepada pembatasan yang ditetapkan dengan undangundang dengan maksud semata-mata untuk menjamin pengakuan serta penghormatan atas hak dan kebebasan orang lain dan untuk memenuhi tuntutan yang adil sesuai dengan pertimbangan moral, nilai-nilai agama, keamanan, dan ketertiban umum dalam suatu masyarakat demokratis". Ketiga, Pasal 29 (1) UUD 1945 berbunyi bahwa, "Negara berdasar atas Ketuhanan Yang Maha Esa”. Keempat, Pasal 29 Ayat (2) UUD 1945 bahwa, "Negara menjamin kemerdekaan tiap-tiap penduduk untuk memeluk agamanya masingmasing dan untuk beribadat menurut agamanya dan kepercayaannya itu”.

Harus diakui, memang di dalam praktiknya Indonesia tidaklah sepenuhnya memisahkan agama dan negara. Sebab, di berbagai kesempatan terdapat beberapa peraturan perundang-undangan yang mengacu kepada ajaran atau hukum agama. Misalkan Undang-Undang Nomor 1 Tahun 1974 Tentang Perkawinan, Undang-Undang Nomor 21 Tahun 2008 Tentang Perbankan Syariah; dan Undang-Undang Nomor38 Tahun 1999 Juncto Undang-Undang Nomor 23 Tahun 2011 Tentang Pengelolaan Zakat. Namun di sisi yang lain, Kitab Undang-Undang Hukum Pidana sama sekali tidaklah merujuk pada ajaran agama. Begitu juga dengan Kitab Undang-Undang Hukum Perdata. Salah satu isinya adalah membenarkan riba.

Begitu juga dengan liberalisme di Indonesia. Salah satunya adalah nikah beda agama atau nikah lintas agama yang difasilitasi oleh Jaringan Islam Liberal. Larangan nikah beda agama ini dianggap oleh kelompok yang menentangnya sebagai sesuatu bertentangan dengan HAM. Bahkan kelompok ini menggunakan fasilitas internasional untuk melancarkan ide nikah beda agama tersebut (Husaini, 2009: 198).

Begitu juga dengan persoalan maraknya praktik homo dan lesbi. Sungguh sangat ironis sampai hari ini prilaku menyimpang tersebut tidak ditanggapi secara serius oleh negara di mana salah satu dasar negara kita itu adalah Ketuhanan Yang Maha Esa. Baik oleh Presiden dan DPR sebagai lembaga yang diamanatkan oleh UUD 1945 untuk membentuk undang-undang, maupun Mahkamah Konstitusi yang tidak "berani" menyatakan bahwa homo dan lesbi sebagai perbuatan pidana ketika menguji Kitab Undang-Undang Hukum Pidana (Putusan Nomor 46/PUU-XIV/2016).

\section{KESIMPULAN}

Ada 2 (dua) faktor utama yang menyebabkan penyimpangan di dalam penafsiran terhadap Pancasila. Pertama, tidak menggunakan metode yang benar di dalam menafsirkan Pancasila, terutama penafsiran sejarah, penafsiran sistematis, dan penafsiran gramatikal. Kedua, anggapan Soekarno sebagai perumus Pancasila. Tentunya ini tidak benar. Sebab Pancasila versi Soekarno terdiri dari, (i) Kebangsaan; (ii) Internasionalisme atau Peri Kemanusiaan; (iii) Mufakat atau Demokrasi; (iv) Kesejahteraan Sosial; dan (v) Ketuhanan.

Ada beberapa implikasi yang ditimbulkan dari pemahaman yang keliru terhadap Pancasila itu. Di antaranya, pertama, terdapatnya beberapa peraturan perundang-undangan yang bertentangan dengan hukum agama terutama syariat Islam. Kedua, munculnya paham yang bertentangan dengan nilainilai Pancasila. Di antara paham-paham itu adalah sekulerisme, pluralisme, dan liberalisme. Ketiga, adanya perbuatan atau tindakan yang bertentangan dengan ajaran agama.

Karena itu, penyimpangan-penyimpangan terhadap Pancasila ini mestilah diluruskan. Sehingga, segala peraturan perundang-undangan di Indonesia, paham-paham, dan perbuatan atau tindakan tidak boleh bertentangan dengan ajaranajaran agama. Sebab, salah satu sila dari Pancasila itu adalah Ketuhanan Yang Maha Esa.

\section{DAFTAR KEPUSTAKAAN}

Artawijaya. 2012. \#Indonesia Tanpa Liberal, Membongkar Misi Asing dalam Subversif Politik dan Agama. Jakarta: Pustaka Alkautsar. 
Faiz, Pan Mohamad, "Dimensi Judicial Activism dalam Putusan Mahkamah Konstitusi, dalam Jurnal Konstitusi. No. 2 Vol. 13, Juni 2016. Jakarta: Kepaniteraan dan Sekretariat Jenderal Mahkamah Konstitusi Republik Indonesia.

Husaini, Adian. 2009. Membendung Arus Liberalisme di Indonesia, Jakarta: Pustaka Al-Kautsar. 2009. Pancasila Bukan Untuk Menindas Hak Konstitusional Umat Islam, Kesalahpahaman terhadap Pancasila 19452009, Jakarta: Gema Insani.

Lesus, Rizki. 2017. Perjuangan yang Dilupakan, Mengulas Perjuangan Umat Islam yang Ter(di)lupakan dalam Sejarah Indonesia. Yogyakarta: Pro-U Media.

Mertokusumo, Sudikno. 2010. Penemuan Hukum. Yogyakarta: Universitas Atma Jaya.

Mertokusumo, Sudikno dan Pitlo, A. 1993. BabBab Tentang Penemuan Hukum, Bandung: Citra Aditya Bakti.

Marzuki, Peter Mahmud. 2005. Penelitian Hukum. Jakarta: Kencana Prenada Media Group.

Santoso, Kholid O., 2007. Paradigma Baru Memahami Pancasila dan UUD 1945, Cetakan Ke-4, Bandung: Sega Arsy.

Shidarta. 2013. Hukum Penalaran dan Penalaran Hukum, Yogyakarta: Genta Publishing.

Susanti, Dyah Ochtorina dan A'an Efendi, 2013. Penelitian Hukum (Legal Research). Jakarta: Sinar Grafika.

Republik Indonesia, Undang-Undang Dasar Negara Republik Indonesia Tahun 1945.

Republik Indonesia, Undang-Undang Nomor 12 Tahun 2011 Tentang Pembentukan Peraturan Perundang-undangan.

Republik Indonesia, Peraturan Presiden Nomor 74 Tahun 2013 Tentang Pengendalian dan Pengawasan Minuman Beralkohol.

Republik Indonesia, Putusan Mahkamah Konstitusi 46/PUU-XIV/2016 Tentang Pengujian Undang-Undang Nomor 1 Tahun 1946 tentang Peraturan Hukum Pidana atau Kitab Undang-Undang Hukum Pidana Juncto Undang-Undang Nomor 73 Tahun 1958 tentang Menyatakan Berlakunya UndangUndang Nomor 1 Tahun 1946 tentang Peraturan Hukum Pidana Untuk Seluruh Wilayah Republik Indonesia dan Mengubah Kitab Undang-Undang Hukum Pidana.

Weruin, Urbanus Ura, "Logika, Penalaran, dan Argumentasi Hukum", dalam Jurnal Konstitusi. No. 2 Vol. 14, Juni 2017. Jakarta: Kepaniteraan dan Sekretariat Jenderal Mahkamah Konstitusi Republik Indonesia. 